\title{
Reaction of three cyclic thioester ligands with triiron dodecacarbonyl and possible reaction mechanisms
}

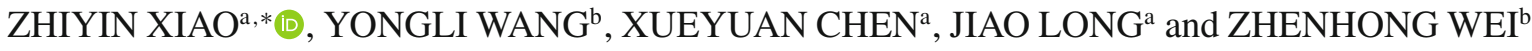 \\ ${ }^{a}$ College of Biological, Chemical Sciences and Engineering, Jiaxing University, Jiaxing 314001, China \\ ${ }^{b}$ Department of Chemistry, Nanchang University, Nanchang 330031, China \\ E-mail: zhiyin.xiao@mail.zjxu.edu.cn
}

MS received 29 May 2017; revised 28 August 2017; accepted 30 August 2017; published online 27 September 2017

\begin{abstract}
Three cyclic thioesters of the formula " $-\mathrm{SCH}_{2} \mathrm{CH}_{2} \mathrm{SCO}\left(\mathrm{CH}_{2}\right)_{\mathrm{n}}-$ " $\left(\mathbf{L}_{\mathbf{1}}, \mathrm{n}=0 ; \mathbf{L}_{\mathbf{2}},=1, \mathbf{L}_{\mathbf{3}}, \mathrm{n}=2\right)$ and their reactions with $\mathrm{Fe}_{3}(\mathrm{CO})_{12}$ are reported. All the reactions produced a known diiron complex, $\left[\mathrm{Fe}_{2}\left(\mu-\mathrm{S}_{2} \mathrm{C}_{2} \mathrm{H}_{4}\right)(\mathrm{CO})_{6}\right](\mathbf{1})$, which suggested that in the reactions, cleavage of C-S bond to generate " $\mathrm{SCH}_{2} \mathrm{CH}_{2} \mathrm{~S}$ " fragment is a common pathway for all the three ligands. In the case of ligand $\mathbf{L}_{\mathbf{2}}$, a new complex $\mathbf{2},\left[\mathrm{Fe}_{2}\left\{\mu-\mathrm{SC}_{2} \mathrm{H}_{4}\left(\mathrm{SCH}_{2}\right)-\kappa\right\}(\mathrm{CO})_{6}\right]$ was isolated and structurally characterized. In the reaction of ligand $\mathbf{L}_{\mathbf{3}}$, an unknown iron carbonyl product was isolated in addition to complex 1. Although its precise structure was not established due to its instability and low yield, its infrared spectrum and decomposing into complex $\mathbf{1}$ implied that the product may be a cluster with higher nuclearity. The experimental observations suggested that with the increase of the ring size of the cyclic thioester ligands, further bond cleavages were involved in the reaction in addition to that leading to complex $\mathbf{1}$.
\end{abstract}

Keywords. Iron-sulfur carbonyl complexes; cyclic thioesters; C-S bond cleavage; reaction mechanism.

\section{Introduction}

Diiron carbonyl complexes are a category of classic organo-iron compounds. Their preparation and further investigations in reactivity, for example, with nucleophiles, proton, and electron transfer gained fresh attention in the past decade because of their structural resemblance to the diiron subunit of [FeFe]-hydrogenase, a metalloenzyme with high efficiency and fast reaction rate in catalyzing both hydrogen evolution and oxidation. ${ }^{1-8}$ In the research, $\mathrm{Fe}_{3}(\mathrm{CO})_{12}$ has been the main precursor to synthesize complexes possessing a core of " $\mathrm{Fe}_{2}(\mathrm{CO})_{6-\mathrm{x}}$ " $(\mathrm{x}=1,2) .{ }^{9}$ This triiron precursor reacts with a variety of ligands of donor atoms $\mathrm{S}, \mathrm{N}, \mathrm{P}$ and $\mathrm{C}$. Depending on the nature of a ligand employed, reaction products can be very diverse. In most cases, not all the products are isolable. Complexes of diiron core are probably the most common products ${ }^{10-13}$ and tetrairon or clusters with higher nuclearity are also not uncommon. Simple thiolates or bidentate dithiolate lead mostly to diiron complexes. But ligands with mixed donor atoms

\footnotetext{
*For correspondence
}

could have much more complicated reactions. Breaking bonds of the ligands and thus forming new ones are often encountered. ${ }^{14-22}$ The latter type of reactions offers often novel iron-carbonyl complexes.

In this study, we report the synthesis of three cyclic thioester ligands, $\mathbf{L}_{1-3}$ and their reactions with $\mathrm{Fe}_{3}(\mathrm{CO})_{12}$. All the reactions involved ring-opening to generate 1,2-ethanedithiolate which was present in the commonly isolated diiron hexacarbonyl complex, $\left[\mathrm{Fe}_{2}\left(\mu-\mathrm{S}_{2} \mathrm{C}_{2} \mathrm{H}_{4}\right)(\mathrm{CO})_{6}\right](\mathbf{1}) .{ }^{23,24}$ In addition to this known complex, other complexes could also be isolated depending on the ring-size of the ligands. NMR, infrared spectroscopies and X-ray single crystal diffraction analysis were used to identify some of the isolated products. Possible reaction mechanisms of the cyclic thioester ligands with triiron dodecacarbonyl are proposed.

\section{Experimental}

\subsection{General procedures}

All the reactions were carried out under an argon atmosphere using standard Schlenk techniques. All the solvents were

Electronic supplementary material: The online version of this article (doi:10.1007/s12039-017-1372-5) contains supplementary material, which is available to authorized users. 
appropriately dried prior to use. The precursor $\mathrm{Fe}_{3}(\mathrm{CO})_{12}$ was prepared using the literature procedure. ${ }^{25}$ 1,3-dithiolane-2thione, ${ }^{26}$ 1,3-dithiolan-2-one $\left(\mathbf{L}_{\mathbf{1}}\right),{ }^{27}$ 1,4-dithian-2-one $\left(\mathbf{L}_{\mathbf{2}}\right)^{28}$ and 1,4-dithiepan-5-one $\left(\mathbf{L}_{3}\right)^{29}$ were synthesized following literature methods with slight modifications. 1,2-ethaneditiol was purchased from Alfa Aesar. All operations were manipulated in a fumehood because of the obnoxious odor of 1,2-ethanedithiol. Infrared spectra were recorded using a solution cell with a spacer of $0.1 \mathrm{~mm}$ for $\mathrm{CH}_{2} \mathrm{Cl}_{2}$ solution on Scimitar 2000 (Varian). NMR spectral data were collected on Bruker Advance 400/600 MHz or Varian MR-400 with tetramethylsilane as internal standard. Elemental analysis was performed by the Center of analysis and testing at Nanchang University (Vario EL III elemental analyzer).

\subsection{Crystallographic data collection and structure determination}

In the data collection for X-ray single crystal diffraction analysis of complex 2 , standard procedures were used for mounting the crystals on a Bruker Smart System CCD at 293(2) K. The crystals were routinely coated with paraffin oil before being mounted. Intensity data were collected using Mo-K $\alpha$ radiation $(\lambda=0.71073 \AA ̊ ㇒)$ at $293 \mathrm{~K}$ using $\varphi$ - and $\omega$-scan mode. The SAINT and SADABS programs in the APPEX 2 software package were used for integration and absorption correction. The structure of complex $\mathbf{2}$ was solved by direct method using SHELXS-97 program and refined on $F^{2}$ with XSHELL6.3.1, all non-hydrogen atoms being modelled anisotropically.

\subsection{Synthesis}

2.3a Preparation of 1,3-dithiolane-2-thione: A mixture of $\mathrm{CS}_{2}(10 \mathrm{~mL}, 0.166 \mathrm{~mol})$ and $\mathrm{NaOH}$ solution $(5 \mathrm{~g} \mathrm{NaOH}$ in $10 \mathrm{~mL} \mathrm{H}_{2} \mathrm{O}$ ) were vigorously stirred at room temperature. A deep red oily liquid started to form at the interface when $\mathrm{n}-\mathrm{Bu}_{4} \mathrm{NBr}(0.2 \mathrm{~g}, 0.6 \mathrm{mmol})$ was added. After being stirred for $10 \mathrm{~min}, 1,2$-dibromoethane $(1 \mathrm{~mL}, 0.012 \mathrm{~mol})$ was introduced in dropwise fashion. The color of the mixture turned slowly to yellow. A minimum amount of dichloromethane and $\mathrm{H}_{2} \mathrm{O}$ were added after reaction for $24 \mathrm{~h}$. The combined organic phase was extracted with dichloromethane $(3 \times 15$ $\mathrm{mL}$ ) and dried over anhydrous $\mathrm{MgSO}_{4}$. Removal of the solvents yielded a green-yellow oil product.

Yield: $70 \%(0.6 \mathrm{~g})$. Microanalysis for $\mathrm{C}_{3} \mathrm{H}_{4} \mathrm{~S}_{3}(\mathrm{FW}=$ 136.25), calc. (\%): C, 26.45; H, 2.96; found (\%): C, 27.03, $\mathrm{H}, 2.82$. IR (DCM, $\left.\mathrm{cm}^{-1}\right): \nu_{\mathrm{C}=\mathrm{S}}, 1074 .{ }^{1} \mathrm{H}$ NMR $(\delta, \mathrm{ppm}$ in $\left.\mathrm{CDCl}_{3}, 298 \mathrm{~K}\right): 3.97$ (s, 4H, 2CH $\left.\mathrm{H}_{2}\right) .{ }^{13} \mathrm{C} \mathrm{NMR}(\delta$, ppm in $\left.\mathrm{CDCl}_{3}, 298 \mathrm{~K}\right): 228.9(C=\mathrm{S}), 43.9\left(\mathrm{CH}_{2}\right)$.

\section{3b 1,3-dithiolan-2-one $\left(\boldsymbol{L}_{\mathbf{1}}\right):$ 1,3-dithiolane-2-thione} $(0.5 \mathrm{~g}, 3.68 \mathrm{mmol})$ and $\mathrm{Hg}(\mathrm{OAc})_{2}(3.17 \mathrm{~g}, 9.2 \mathrm{mmol})$ were mixed in $\mathrm{CHCl}_{3} / \mathrm{AcOH}(3: 1,20 \mathrm{~mL})$ under Ar. The mixture was stirred at room temperature over night. A white precipitate formed in the reaction was filtered off. The filtrate was extracted with $\mathrm{NaHCO}_{3}$ solution $(3 \times 200 \mathrm{~mL})$ and dried over anhydrous $\mathrm{MgSO}_{4}$. A pale yellow oily liquid was obtained after the evaporation of the solvents.

Ligand $\mathbf{L}_{\mathbf{1}}$ : Yield: $78 \%(0.39 \mathrm{~g})$. IR $\left(\mathrm{DCM}, \mathrm{cm}^{-1}\right): \nu_{\mathrm{C}=\mathrm{O}}$, 1673. ${ }^{1} \mathrm{H}$ NMR $\left(\delta\right.$, ppm in $\left.\mathrm{CDCl}_{3}, 298 \mathrm{~K}\right): 3.67$ (d, $J=1.8$ $\left.\mathrm{Hz}, 4 \mathrm{H}, 2 \mathrm{CH}_{2}\right)$.

\section{3c 1,4-dithian-2-one $\left(\boldsymbol{L}_{2}\right)$ and 1,4-dithiepan-5-one} $\left(\boldsymbol{L}_{3}\right)$ : A solution of 1,2-ethanedithiol $(0.5 \mathrm{~mL}, 6 \mathrm{mmol})$ and triethylamine $(1.68 \mathrm{~mL}, 12 \mathrm{mmol})$ in dichloromethane $(80$ $\mathrm{mL}$ ) was cooled down to $-78^{\circ} \mathrm{C}$ with an ice-acetone bath under Ar. To the pre-cooled mixture was dropwise added a solution of 3-chloroacetyl chloride $(0.48 \mathrm{~mL}, 6 \mathrm{mmol})$ in dichloromethane $(40 \mathrm{~mL})$ over $1.5 \mathrm{~h}$. After the addition, a white precipitate of triethylamine hydrochloride formed. The reaction mixture was left for stirring at room temperature for further $2 \mathrm{~h}$. The precipitate was filtered off and the filtrate was washed with water $(3 \times 75 \mathrm{~mL})$ and dried over $\mathrm{MgSO}_{4}$. Removal of the solvent under reduced pressure gave a clear liquid.

Ligand $\mathbf{L}_{2}$ : Yield: $60 \%$ (0.48 g). Microanalysis for $\mathrm{C}_{4} \mathrm{H}_{6} \mathrm{OS}_{2}$ $(\mathrm{FW}=134.21)$, calc. $(\%): \mathrm{C}, 35.80 ; \mathrm{H}, 4.51$; found (\%): $\mathrm{C}$, 35.99, H, 4.32. IR (DCM, $\left.\mathrm{cm}^{-1}\right): v_{\mathrm{C}=\mathrm{O}}, 1674 .{ }^{1} \mathrm{H}$ NMR $(\delta$, ppm in $\left.\mathrm{CDCl}_{3}, 298 \mathrm{~K}\right): 3.45$ (s, $\left.2 \mathrm{H}, \mathrm{COCH}_{2}\right), 3.41$ (t, $J=4$ $\mathrm{Hz}, 2 \mathrm{H}, \mathrm{COSCH}_{2}$ ), 3.13 (t, $\left.\mathrm{J}=4 \mathrm{~Hz}, 2 \mathrm{H}, \mathrm{CH}_{2}\right) .{ }^{13} \mathrm{C} \mathrm{NMR}$ $\left(\delta\right.$, ppm in $\left.\mathrm{CDCl}_{3}, 298 \mathrm{~K}\right): 196.8(\mathrm{C}=\mathrm{O}), 35.6\left(\mathrm{CH}_{2}\right), 31.4$ $\left(\mathrm{CH}_{2}\right), 26.0\left(\mathrm{CH}_{2}\right)$.

Ligand $\mathbf{L}_{\mathbf{3}}$ was analogously prepared by using 3chloropropanoyl chloride $(0.50 \mathrm{~mL}, 6 \mathrm{mmol})$ to replace 3 chloroacetyl chloride. The ligand was isolated as a white solid.

Ligand $\mathbf{L}_{\mathbf{3}}$ : Yield: $34 \%(0.59 \mathrm{~g})$. Microanalysis for $\mathrm{C}_{5} \mathrm{H}_{8} \mathrm{OS}_{2}(\mathrm{FW}=148.24)$, calc. $(\%): \mathrm{C}, 40.51 ; \mathrm{H}, 5.44$; found (\%): C, 40.06, H, 5.31. IR (DCM, cm $\left.{ }^{-1}\right): \nu_{\mathrm{C}=\mathrm{O}}, 1671 .{ }^{1} \mathrm{H}$ NMR $\left(\delta, p p m\right.$ in $\left.\mathrm{CDCl}_{3}, 298 \mathrm{~K}\right): 3.58(\mathrm{~m}, J=3.15 \mathrm{~Hz}$, $\left.2 \mathrm{H}, \mathrm{COCH}_{2}\right), 3.08\left(\mathrm{~s}, 2 \mathrm{H}, \mathrm{C}^{2} H_{2}\right), 2.76(\mathrm{q}, J=4.8 \mathrm{~Hz}, 2 \mathrm{H}$, $\left.\mathrm{COSCH}_{2}\right), 2.13\left(\mathrm{~m}, \mathrm{~J}=6.6 \mathrm{~Hz}, 2 \mathrm{H}, \mathrm{C}^{7} \mathrm{H}_{2}\right) .{ }^{13} \mathrm{CNMR}(\delta, \mathrm{ppm}$ in $\left.\mathrm{CDCl}_{3}, 298 \mathrm{~K}\right): 197.5(\mathrm{C}=\mathrm{O}), 43.8\left(\mathrm{CH}_{2}\right), 40.8\left(\mathrm{CH}_{2}\right)$, $28.7\left(\mathrm{CH}_{2}\right), 27.9\left(\mathrm{CH}_{2}\right)$.

\section{3d Reaction of ligands $\boldsymbol{L}_{\mathbf{1 - 3}}$ with $\mathrm{Fe}_{3}(\mathrm{CO})_{12}$}

Ligand $\mathbf{L}_{\mathbf{1}}$ : To a reaction flask containing THF $(20 \mathrm{~mL})$ were added $\mathbf{L}_{\mathbf{1}}$ (72 $\left.\mathrm{mg}, 0.6 \mathrm{mmol}\right)$ and $\mathrm{Fe}_{3}(\mathrm{CO})_{12}(303 \mathrm{mg}$, $0.6 \mathrm{mmol}$ ) under Ar. The reaction was heated to reflux for $2 \mathrm{~h}$ and the color of the reaction mixture turned from dark-green to brownish red. The reaction was cooled before being concentrated for purification using flash chromatography (eluent: ethyl acetate/petroleum ether $=1 / 8)$. The product $($ complex $\mathbf{1})$ was isolated as brownish red solid.

Complex 1: Yield: $37 \%(0.080 \mathrm{~g})$. IR $\left(\mathrm{DCM}, \mathrm{cm}^{-1}\right): \nu_{\mathrm{C}=\mathrm{O}}$, 2076, 2036, 2000, 1995. ${ }^{1} \mathrm{H}$ NMR ( $\delta$, ppm in $\mathrm{CDCl}_{3}, 298 \mathrm{~K}$ ): 2.37 (s, $\left.4 \mathrm{H}, 2 \mathrm{SCH} \mathrm{H}_{2}\right) .{ }^{13} \mathrm{C}$ NMR $\left(\delta, \mathrm{ppm}\right.$ in $\left.\mathrm{CDCl}_{3}, 298 \mathrm{~K}\right)$ : $208.4(\mathrm{CO}), 36.4\left(\mathrm{SCH}_{2}\right)$.

Ligand $\mathbf{L}_{\mathbf{2}}$ : A solution of $\mathbf{L}_{\mathbf{2}}(80 \mathrm{mg}, 0.6 \mathrm{mmol})$ and $\mathrm{Fe}_{3}(\mathrm{CO})_{12}$ (303 mg, $0.6 \mathrm{mmol}$ ) was dissolved in tetrahydrofuran (THF, $20 \mathrm{~mL}$ ) under Ar. The mixture was heated under stirring at $65^{\circ} \mathrm{C}$ for $2 \mathrm{~h}$. When the color turned from dark green to red-brown, the solvent was evaporated to give crude product 


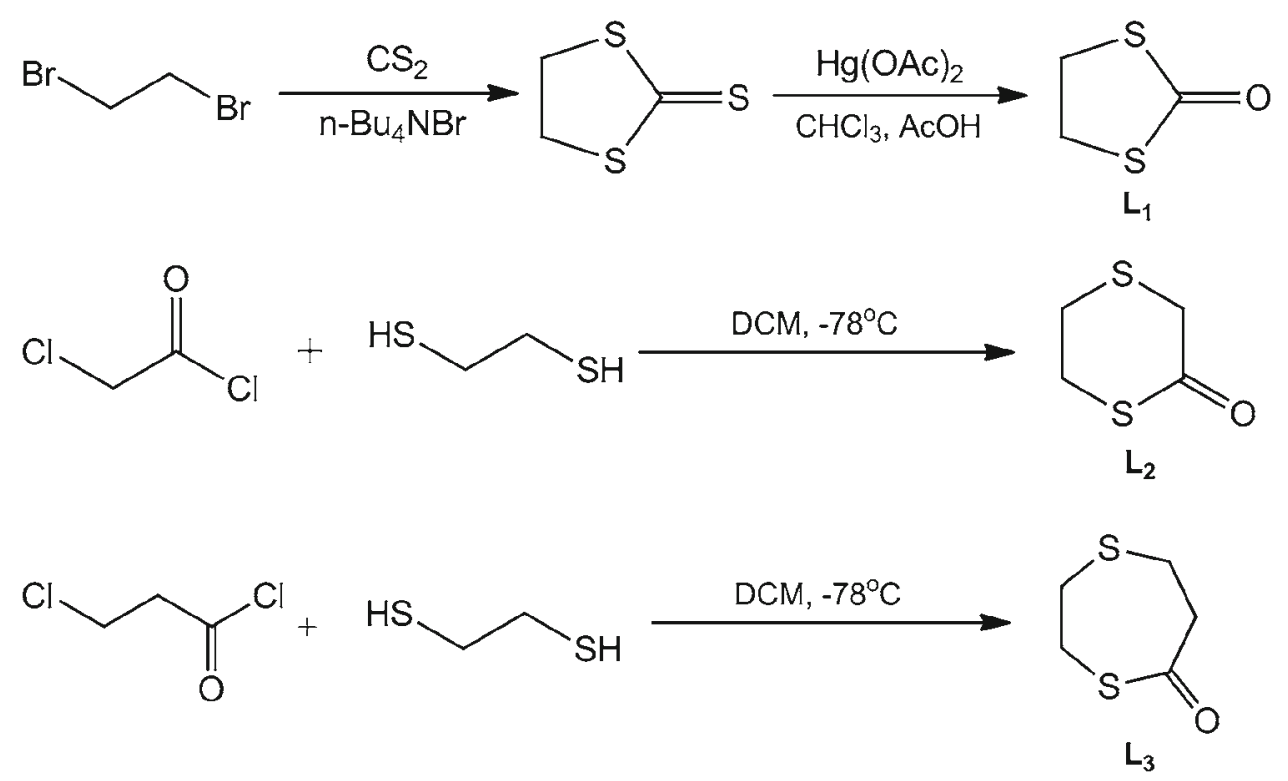

Scheme 1. Syntheses of ligands $\mathbf{L}_{\mathbf{1}-\mathbf{3}}$.

which was purified by column chromatography on silica gel with an eluent of a volume mixture of ethyl acetate/petroleum ether (1/8). Two products, $\left[\mathrm{Fe}_{2}\left(\mu-\mathrm{S}_{2} \mathrm{C}_{2} \mathrm{H}_{4}\right)(\mathrm{CO})_{6}\right]$ (1) and $\left[\mathrm{Fe}_{2}\left(\mu^{2}, \kappa-\mathrm{S}, \mathrm{C}-\mathrm{SC}_{2} \mathrm{H}_{4} \mathrm{SCH}_{2}\right)(\mathrm{CO})_{6}\right]$ (2) were successively isolated. Recrystallization of complex 2 from a mixed solvent of dichloromethane and hexanes (1/3) afforded yellow crystals suitable for X-ray single crystal diffraction analysis.

Complex 1: Yield: $16 \%$ (0.035 g). Complex 2: Yield: $38 \%$ $(0.087 \mathrm{~g})$. Microanalysis for $\mathrm{Fe}_{2} \mathrm{C}_{9} \mathrm{H}_{6} \mathrm{~S}_{2} \mathrm{O}_{6}(\mathrm{FW}=385.8)$, calc. (\%): C, 28.01, H, 1.57; found (\%): C, 28.01, H, 1.25. IR $\left(\mathrm{DCM}, \mathrm{cm}^{-1}\right): v_{\mathrm{C}=\mathrm{O}}, 2066,2022,1994,1981 .{ }^{1} \mathrm{H}$ NMR $(\delta$, ppm in $\left.\mathrm{CDCl}_{3}, 298 \mathrm{~K}\right): 3.5-3.6\left(\mathrm{~m}, 1 \mathrm{H}, \mathrm{C}^{8} \mathrm{H}_{a} \mathrm{H}_{\mathrm{b}}\right), 3.3-3.4$ $\left(\mathrm{m}, 1 \mathrm{H}, \mathrm{C}^{8} \mathrm{H}_{\mathrm{a}} H_{b}\right), 2.5-2.7\left(\mathrm{~m}, 2 \mathrm{H}, \mathrm{SC}^{7} H_{a} H_{b}\right), 1.63(\mathrm{~d}-\mathrm{d}, J$ $\left.=11.4 \mathrm{~Hz}, 1 \mathrm{H}, \mathrm{C}^{9} H_{a} \mathrm{H}_{\mathrm{b}}\right), 0.58\left(\mathrm{~d}, J=11.4 \mathrm{~Hz}, 1 \mathrm{H}, \mathrm{C}^{9} \mathrm{H}_{\mathrm{a}} H_{b}\right)$ (refer to Figure 2 for the labelling of the carbon atom). ${ }^{13} \mathrm{C}$ $\operatorname{NMR}\left(\delta, p p m\right.$ in $\left.\mathrm{CDCl}_{3}, 298 \mathrm{~K}\right): 214.96(C \mathrm{O}), 211.09(C \mathrm{O})$, $206.02(\mathrm{CO}), 47.48\left(\mathrm{SCH}_{2}\right), 26.60\left(\mathrm{SCH}_{2}\right), 2.69\left(\mathrm{FeCH}_{2} \mathrm{~S}\right)$.

Ligand $\mathbf{L}_{\mathbf{3}}$ : The reaction of the ligand with the triiron was analogously performed with $\mathbf{L}_{\mathbf{3}}(0.089 \mathrm{~g}, 0.6 \mathrm{mmol})$. The reaction produced first complex 1 and then second unknown product as a claret-colored solid (less than $5 \mathrm{mg}$ ). This complex is labile and only its IR spectrum was obtained.

Complex 1: Yield: $32 \%(0.071 \mathrm{~g})$. Unknown product: Microanalysis (found \%): C, 28.69; H, 3.79. IR (DCM, $\mathrm{cm}^{-1}$ ): $\nu_{\mathrm{C}=\mathrm{O}}, 2074,2040,2008,1976,1906$.

\section{Results and Discussion}

\subsection{Synthesis}

As shown in Scheme 1, cyclic thioester ligands $\mathbf{L}_{\mathbf{1 - 3}}$ with the same fragment, " $\mathrm{SCH}_{2} \mathrm{CH}_{2} \mathrm{SCO}$ ", were prepared by following the literature procedures via two-step $\left(\mathbf{L}_{1}\right)$ or one-step $\left(\mathbf{L}_{\mathbf{2}-3}\right)$ reactions. ${ }^{27-29}$ Heating a solution of $\mathbf{L}_{1-3}$ and $\mathrm{Fe}_{3}(\mathrm{CO})_{12}(1 / 1)$ in tetrahydrofuran under reflux resulted in the formation of complex $\mathbf{1}$, $\left[\mathrm{Fe}_{2}\left(\mu-\mathrm{S}_{2} \mathrm{C}_{2} \mathrm{H}_{4}\right)(\mathrm{CO})_{6}\right]$, a widely reported diiron com$\operatorname{plex}^{23,24}$ (Scheme 2). For ligand $\mathbf{L}_{\mathbf{1}}$, this complex was the solely isolable product. But for the other ligands, additional complexes were isolated, Scheme 2. In the case of ligand $\mathbf{L}_{2}$, a diiron complex (2) was isolated in good yield (38\%). In this complex, the bridging moiety is associated with a thioether thiol, 2-(methylthio)ethanethiol. The thiolate bridged to the two iron atoms in $\mu$-manner, as found in many other diiron complexes, whereas the thioether $\mathrm{S}$ and the carbene carbon equivalent to deprotonated form $\left(\mathrm{SCH}_{2}\right)$ of the methylthio group $\left(\mathrm{SCH}_{3}\right)$ acted as another bridge in $\kappa$-mode between the two iron atoms. This complex was readily crystallized as yellow crystal blocks from a mixed solution of dichloromethane and hexanes (1/3) under Ar atmosphere. The yields for complexes $\mathbf{1}$ and $\mathbf{2}$ were approximately at a ratio of $1 / 2$. The decent yield allowed full characterization of complex $\mathbf{2}$ by using FTIR, ${ }^{1} \mathrm{H}$ NMR,${ }^{13} \mathrm{C}$ NMR, elemental analysis and X-ray single crystal structure analysis. For ligand $\mathbf{L}_{\mathbf{3}}$, although an additional claret product was isolated in extremely small quantity, its instability did not allow us to complete further characterization except infrared spectroscopic and elemental analysis.

The infrared spectra of all the isolated complexes are shown in Figure 1. For comparison, the spectrum of the known complex $\mathbf{1}$ in dichloromethane was also presented $\left(2076,2036,2000\right.$, and $\left.1995 \mathrm{~cm}^{-1}\right)$. Compared to the spectrum of complex 1 , complex 2 shows a similar spectral profile with absorption bands at 2066, 2022, 1994 and $1981 \mathrm{~cm}^{-1}$. All the absorption bands undergo "red-shift" by about $10 \mathrm{~cm}^{-1}$. This shift 


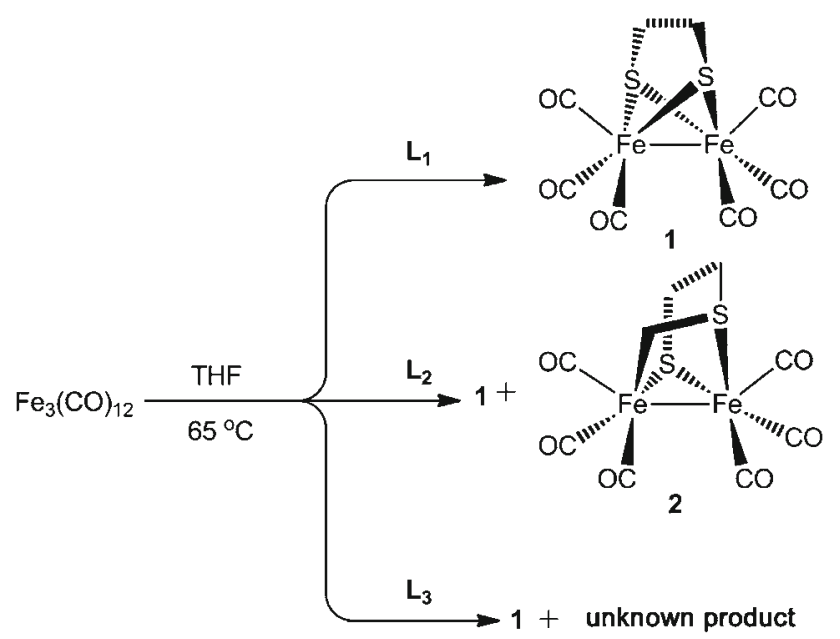

Scheme 2. Reaction of cyclic thioester ligands $\mathbf{L}_{\mathbf{1}-\mathbf{3}}$ with $\mathrm{Fe}_{3}(\mathrm{CO})_{12}$ and structures of isolated iron carbonyl products.

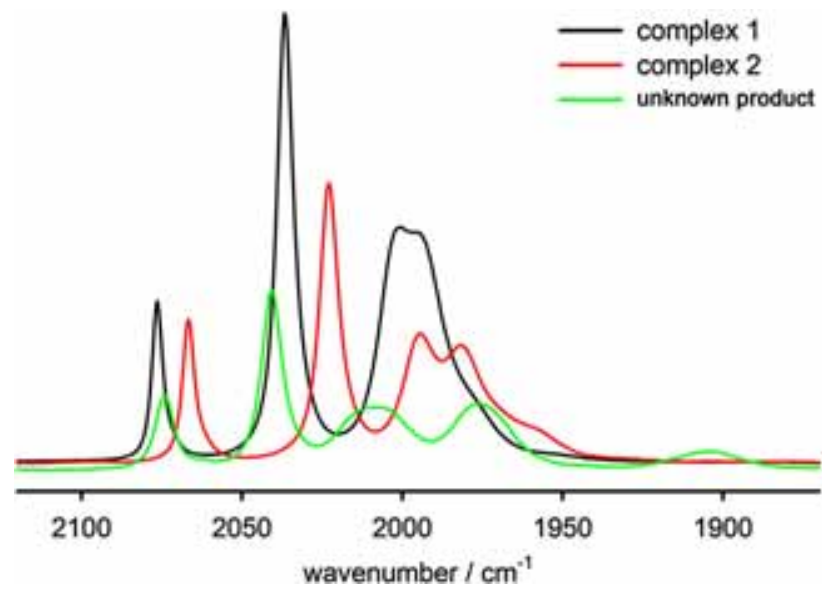

Figure 1. Infrared spectra of the isolated iron carbonyl complexes in dichloromethane.

is certainly attributed to the strong electron-donating ability of the carbene group presented in the complex. For the unknown product, as shown in Figure 1, which does comprise of the spectral characteristic absorption bands analogous to diiron complexes such as complex 1 but additional absorption bands indicate that it possesses more complicated iron-carbonyl unit in addition to a " $\mathrm{Fe}_{2}(\mathrm{CO})_{6}$ " unit. This is confirmed by its slow decomposition which produced a species with identical infrared spectrum to that of complex 1. Previously, we reported clusters of tri-diiron-carbonyl units. ${ }^{13}$ The clusters showed also multiplicity in their infrared spectra. Therefore, it is likely that the unknown product is a cluster containing more than one diiron-carbonyl units.

\subsection{Crystallographic analysis of complex 2}

Diffusion of hexanes into a dichloromethane solution of complex 2 afforded yellow crystals suitable for X-ray single crystal diffraction analysis by storing the mixture
Table 1. Crystallographic data and processing parameters for complex 2.

\begin{tabular}{|c|c|}
\hline Formula & $\mathrm{C}_{9} \mathrm{H}_{6} \mathrm{Fe}_{2} \mathrm{O}_{6} \mathrm{~S}_{2}$ \\
\hline Formula weight (g/mol) & 385.98 \\
\hline Temperature $(\mathrm{K})$ & $296(2)$ \\
\hline Crystal System & Monoclinic \\
\hline Space group & $\mathrm{P} 21 / \mathrm{n}$ \\
\hline $\mathrm{a}(\AA)$ & $9.203(2)$ \\
\hline $\mathrm{b}(\AA)$ & $13.912(3)$ \\
\hline$c(\AA)$ & $11.055(3)$ \\
\hline$\alpha(\operatorname{deg})$ & 90 \\
\hline$\beta(\operatorname{deg})$ & $101.907(2)$ \\
\hline$\gamma(\operatorname{deg})$ & 90 \\
\hline $\mathrm{V}\left(\AA^{3}\right)$ & $1384.9(5)$ \\
\hline $\mathrm{Z}$ & 4 \\
\hline Crystal size (mm) & $0.34 \times 0.32 \times 0.30$ \\
\hline $\mathrm{D}_{\text {calc }}\left(\mathrm{g} / \mathrm{cm}^{3}\right)$ & 1.851 \\
\hline Absorption coefficient $\left(\mathrm{mm}^{-1}\right)$ & 2.411 \\
\hline$F\left(\begin{array}{llll}0 & 0 & 0\end{array}\right)$ & 768.0 \\
\hline$\theta\left({ }^{\circ}\right)$ & 2.39 to 28.46 \\
\hline Limiting indices & $\begin{array}{c}-12<=\mathrm{h}<=12, \\
-18<=\mathrm{k}<=17 \\
-14<=\mathrm{l}<=14\end{array}$ \\
\hline Reflections collected & 12481 \\
\hline Reflections unique & $3464\left[R_{(\mathrm{int})}\right]=0.0264$ \\
\hline Completeness to $\theta_{\max }$ & $99.1 \%$ \\
\hline Max. and min. transmission & 0.485 and 0.58 \\
\hline GOF on $F^{2}$ & 1.068 \\
\hline Final $R$ indices $[I>2 \sigma(I)]$ & $\begin{array}{l}\mathrm{R}_{1}=0.0535, \mathrm{w} R_{2}= \\
0.1578\end{array}$ \\
\hline Final $\mathrm{R}$ indices [all data] & $\begin{array}{l}\mathrm{R}_{1}=0.0820, \mathrm{w} R_{2}= \\
\quad 0.1847\end{array}$ \\
\hline Largest diff. peak and hole $\left(\mathrm{e} / \AA^{3}\right)$ & 1.931 and -0.422 \\
\hline
\end{tabular}

$R_{1}=\Sigma\left\|F_{\mathrm{O}}|-| F \mathrm{c}\right\| / \Sigma\left|F_{\mathrm{o}}\right|$ and $\mathrm{w} R_{2}=\left[\Sigma\left(\left|F_{o}^{2}-F_{\mathrm{c}}^{2}\right|\right)^{2} /\right.$ $\left.\Sigma\left(\mathrm{w} F_{\mathrm{o}}^{2}\right)^{2}\right]^{1 / 2}$

at $-20^{\circ} \mathrm{C}$ for several days. Its crystallographic details and selected bond lengths and angles are tabulated in Tables 1 and 2, respectively. As shown in Figure 2, the wobbling of the bridging head led to severe disorder in its crystal structure. Due to the disorder, the bridging group in complex 2 exhibited disorder over two positions, $\mathrm{S}(1)-\mathrm{C}(7)-\mathrm{C}(8)-\mathrm{C}(9)-\mathrm{S}(2)$ and $\mathrm{S}(1 \mathrm{~A})-\mathrm{C}(7 \mathrm{~A})-$ $\mathrm{C}(8 \mathrm{~A})-\mathrm{C}(9 \mathrm{~A})-\mathrm{S}(2 \mathrm{~A})$. The occupancy between the two is $0.64 / 0.36$. Nevertheless, in complex 2 , in addition to the $\mu$-thiolato bridging mode, the two iron atoms are also bridged by " $\mathrm{SCH}_{2}$ " in $\kappa$-mode which lowered the symmetry of the molecule. The entire bridging moiety is " $\mathrm{SCH}_{2} \mathrm{CH}_{2} \mathrm{SCH}_{2}$ ".

Structurally, the complex is analogous to those with bridging moieties of " $\mathrm{SCH}_{2} \mathrm{~S}$ (or $\left.\mathrm{CH}_{2}\right) \mathrm{CH}_{2} \mathrm{SCH}_{2}$ " 14 and " $\mathrm{SeCH}_{2} \mathrm{SCH}_{2} \mathrm{SeCH}_{2}{ }{ }^{16}$ It is this bridging mode that allows the entire moiety more flexibility compared to those diiron complexes with two $\mu$-thiolato bridges and 
Table 2. Selected bond lengths $(\AA)$ and angles $\left(^{\circ}\right)$ for complex 2.

\begin{tabular}{llll}
\hline $\mathrm{Fe}(1)-\mathrm{Fe}(2)$ & $2.5996(10)$ & $\angle \mathrm{Fe}(2)-\mathrm{S}(1)-\mathrm{Fe}(1)$ & $71.11(9)$ \\
$\mathrm{Fe}(1)-\mathrm{S}(1)$ & $2.238(4)$ & $\angle \mathrm{S}(2)-\mathrm{C}(9)-\mathrm{Fe}(2)$ & $102.9(5)$ \\
$\mathrm{Fe}(1)-\mathrm{S}(2)$ & $2.261(2)$ & $\angle \mathrm{C}(9)-\mathrm{S}(2)-\mathrm{Fe}(1)$ & $104.1(5)$ \\
$\mathrm{Fe}(2)-\mathrm{S}(1)$ & $2.232(3)$ & $\angle \mathrm{C}(9)-\mathrm{Fe}(2)-\mathrm{Fe}(1)$ & $75.7(4)$ \\
$\mathrm{Fe}(2)-\mathrm{C}(9)$ & $2.307(17)$ & $\angle \mathrm{S}(1)-\mathrm{Fe}(2)-\mathrm{Fe}(1)$ & $54.55(12)$ \\
$\mathrm{S}(2)-\mathrm{C}(9)$ & $1.522(18)$ & $\angle \mathrm{S}(1)-\mathrm{Fe}(1)-\mathrm{Fe}(2)$ & $54.34(10)$ \\
$\mathrm{Fe}(1)-\mathrm{C}(1)$ & $1.798(7)$ & $\angle \mathrm{S}(2)-\mathrm{Fe}(1)-\mathrm{Fe}(2)$ & $76.88(15)$ \\
$\mathrm{Fe}(2)-\mathrm{C}(2)$ & $1.801(7)$ & & \\
\hline
\end{tabular}

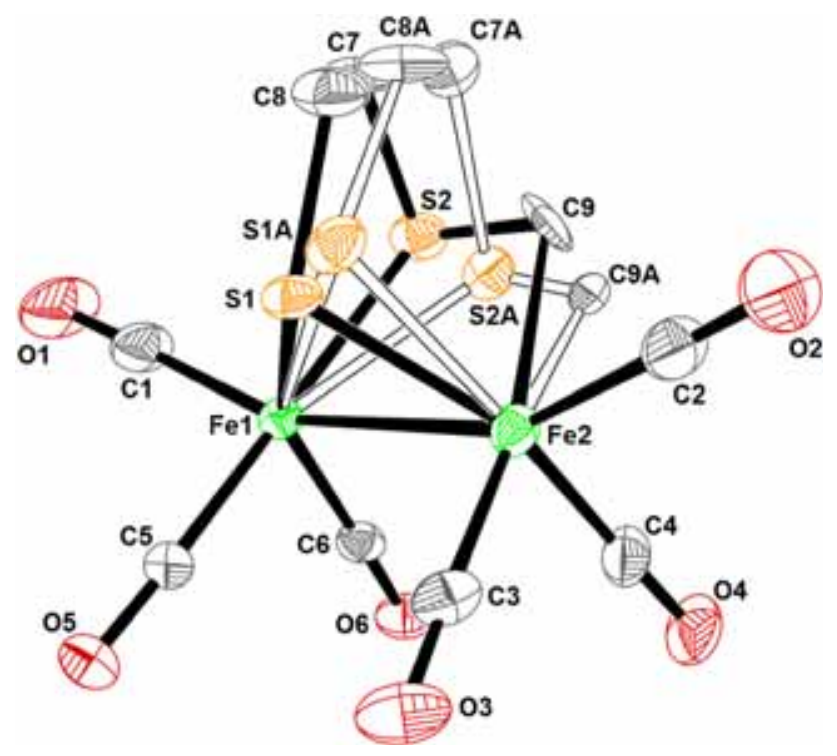

Figure 2. Crystal structure of complex 2 with disorder (ellipsoids were drawn at a thermal probability of $50 \%$ and hydrogen atoms were omitted for clarity reasons).

thus exhibited the observed disorder. NMR spectra of the complex echo in accordance with the structure. As seen in Figure S10 (Supplementary Information), ${ }^{13} \mathrm{C}$ NMR showed cleanly three signals belonging to the organic bridging linkage (" $\mathrm{SC}^{8} \mathrm{H}_{2} \mathrm{C}^{7} \mathrm{H}_{2} \mathrm{SC}^{9} \mathrm{H}_{2}$ ") in high field besides three peaks in low field which could be assigned to the bound CO. However, its ${ }^{1} \mathrm{H}$ NMR spectrum (Figure S11 in SI) is more complicated. Due to cyclic effect, the two protons on carbon C(9) were split to a pair of doublet, 1.63 and $0.58 \mathrm{ppm}$, respectively. While one of the protons shows a doublet at $0.58 \mathrm{ppm}$ with the coupling constant of $11.4 \mathrm{~Hz}$, the other proton exhibits a pseudo-quartet signal at $1.63 \mathrm{ppm}$. The fine structure of the signals at $1.63 \mathrm{ppm}$ can be attributed to remote coupling with the protons on $\mathrm{C}(7)$ with a small coupling constant $(1.2 \mathrm{~Hz})$. As being found in other asymmetric analogues we reported recently, ${ }^{30}$ its asymmetry leads to more complicated infrared spectrum compared to complex 1. But, noticeably, the variation does not alter its overall structure compared to other analogous diiron carbonyl complexes reported in the literatures. ${ }^{13,30-37}$

\subsection{Possible reaction mechanisms}

The common product for the three reactions is complex 1 possessing 1,2-dithiolate as bridging linkage. Since all the three ligands have the motif, " $\mathrm{SCH}_{2} \mathrm{CH}_{2} \mathrm{~S}$ ", and one of the sulfur atoms adjacent to the carbonyl group (Scheme 1), this suggests strongly that in the three reactions, the ring opening via two $\mathrm{C}-\mathrm{S}$ bond cleavages generated complex 1. According to our recent calculations, such cleavages occur successively upon the coordination of $\mathrm{S}$ atom to one of the iron atoms of the precursor. ${ }^{30}$ For ligand $\mathbf{L}_{\mathbf{1}}$, the two successive $\mathrm{C}-\mathrm{S}$ bond cleavages released one CO. Thus, it is consistent with the observation that complex $\mathbf{1}$ was the solely isolable product in the reaction. In the reaction of ligand $\mathbf{L}_{2}$ with $\mathrm{Fe}_{3}(\mathrm{CO})_{12}$, in addition to the cleavages related to the formation of complex 1, alternative bond cleavage occurred. In the second bond cleavage, it occurred, likely, after the second iron atom had been assembled. The $\mathrm{CH}_{2}$ group in the fragment $-\mathrm{SCH}_{2} \mathrm{CO}-$ involved in bridging (binding) together with the $\mathrm{S}$ atom to the other iron atom in $\kappa$-mode and this binding initiated the decarboxylation to form complex 2. There is, undoubtedly, additional bond(s) cleavages similar to that occurred in the reaction of ligand $\mathbf{L}_{\mathbf{2}}$ with the triiron precursor. But failure to determine the fine structure of the unknown product generated from the reaction of ligand $\mathbf{L}_{3}$ with $\mathrm{Fe}_{3}(\mathrm{CO})_{12}$ did not allow more detailed elucidation of its reaction mechanism.

\section{Conclusions}

In summary, the synthesis and characterization of three cyclic thioester ligands possessing common " $\mathrm{SCH}_{2} \mathrm{CH}_{2} \mathrm{~S}$ " unit and their reactions with $\mathrm{Fe}_{3}(\mathrm{CO})_{12}$ are reported. The isolation of the same product in all the reactions, complex $\mathbf{1}$, asserts how the bond cleavages occurred upon the reaction with the precursor in the three reactions. The isolation of complex $\mathbf{2}$ in the reaction of ligand $\mathbf{L}_{2}$ with $\mathrm{Fe}_{3}(\mathrm{CO})_{12}$ indicated other pathway(s) of bond cleavage in addition to the $\mathrm{S}-\mathrm{C}$ bond cleavage when the ring size of the ligand increases.

\section{Supplementary Information (SI)}

Crystallographic data for the structural analysis of complex 2 which has been deposited with the Cambridge Crystallographic Data Center, with the number of 895034, 
can be obtained free of charge at http://www.ccdc.cam.ac. uk. NMR spectra of the ligands and the new complex $\mathbf{2}$ are presented in Supplementary Information, available at http:// www.ias.ac.in/chemsci.

\section{Acknowledgements}

We thank the Natural Science Foundation of Zhejiang Province (Grant No. LQ17B01004) and the Key Project for Student Research Training of Jiaxing University (851716048) for supporting this work.

\section{References}

1. Peters J W, Lanzilotta W N, Lemon B J and Seefeldt L C 1998 X-ray crystal structure of the Fe-only hydrogenase (Cpl) from Clostridium pasteurianum to 1.8 angstrom resolution Science 2821853

2. Nicolet Y, Piras C, Legrand P, Hatchikian C E and Fontecilla-Camps J C 1999 Desulfovibrio desulfuricans iron hydrogenase: the structure shows unusual coordination to an active site Fe binuclear center Structure 7 13

3. Vignais P M and Billoud B 2007 Occurrence, classification, and biological function of hydrogenases: An overview Chem. Rev. 1074206

4. Mathur P, Ghosh S, Sarkar A, Satyanarayana C V V, Drake J E and Yang J 1997 Unusual Formation of Vinyl Ether Derivatives in the Reaction of Tributyltin Hydride with Fischer Carbene Complexes Anchored on a Chalcogen-Stabilized Iron Carbonyl Cluster Organometallics 166028

5. Mathur P, Ghosh S, Sarkar A, Satyanarayana C V V and Puranik V G 1997 Chemical Modification of the Metal-Carbene Appendage in New, Trimetallic Adducts of $\mathrm{Fe}_{2}(\mathrm{CO})_{6}\left(\mu-\mathrm{EE}^{\prime}\right)\left(\mathrm{E}=\mathrm{S}, \mathrm{Se}\right.$ and $\mathrm{E}^{\prime}=$ $\mathrm{Se}, \mathrm{Te})$ and Alkynyl Fischer Carbene Complexes $(\mathrm{CO})_{5}$ $\mathrm{MC}(\mathrm{OEt})(\mathrm{C} \equiv \mathrm{CPh})(\mathrm{M}=\mathrm{Cr}, \mathrm{W})$ Organometallics 16 4392

6. Mathur P, Ghosh S, Sarkar A, Satyanarayana C V V, Rheingold A L and Liable-Sands L M 1997 Regioselective Addition of Mixed-Chalcogenide Iron Carbonyl Clusters $\mathrm{Fe}_{2}(\mathrm{CO})_{6}\left(\mu-\mathrm{EE}^{\prime}\right)\left(\mathrm{E} \neq \mathrm{E}^{\prime}, \mathrm{E}, \mathrm{E}^{\prime}=\right.$ $\mathrm{S}, \mathrm{Se}, \mathrm{Te})$ to a Carbon-Carbon Triple Bond Activated by a Metal Carbene Fragment. Structural Characterization of New Trimetallic Adducts $\mathrm{Fe}_{2}(\mathrm{CO})_{6}\{\mu-\mathrm{SC}(\mathrm{Ph}) \mathrm{C}(\mathrm{Te})$ $\left.\left[(\mathrm{OEt}) \mathrm{CCr}(\mathrm{CO})_{5}\right]\right\}, \mathrm{Fe}_{2}(\mathrm{CO})_{6}\{\mu-\mathrm{SC}(\mathrm{Ph}) \mathrm{C}(\mathrm{Se})[(\mathrm{OEt}) \mathrm{C}$ $\left.\left.\mathrm{W}(\mathrm{CO})_{5}\right]\right\}$, and $\mathrm{Fe}_{2}(\mathrm{CO})_{6}\{\mu-\mathrm{SeC}(\mathrm{Ph}) \mathrm{C}(\mathrm{Te})[(\mathrm{OET}) \mathrm{CW}$ (CO) 5 ]\} Organometallics $\mathbf{1 6} 3536$

7. Adams R D, Kwon O S and Miao S 2005 Disulfido Metal Carbonyl Complexes Containing Manganese Acc. Chem. Res. 38183

8. Schilter D, Camara J M, Huynh M T, Hammes-Schiffer S and Rauchfuss T B 2016 Hydrogenase Enzymes and Their Synthetic Models: The Role of Metal Hydrides Chem. Rev. 1168693

9. Li Y and Rauchfuss T B 2016 Synthesis of Diiron(I) Dithiolato Carbonyl Complexes Chem. Rev. 116 7043
10. Adams R D, Babin J E, Wang J G and Wu W G 1989 Cluster Synthesis .24. Synthesis and Characterization of New Sulfur-Containing Tungsten Iron Carbonyl Cluster Complexes Inorg. Chem. 28703

11. Song L C, Gao J, Wang H T, Hua Y J, Fan H T, Zhang X G and Hu Q M 2006 Synthesis and structural characterization of metallocrown ethers containing butterfly $\mathrm{Fe}_{2} \mathrm{~S}_{2}$ cluster cores. Biomimetic hydrogen evolution catalyzed by $\mathrm{Fe}_{2}\left(\mu-\mathrm{SCH}_{2} \mathrm{CH}_{2} \mathrm{OCH}_{2} \mathrm{CH}_{2} \mathrm{~S}\right.$ $\mu)(\mathrm{CO})_{6}$ Organometallics 255724

12. Cheah M H, Tard C, Borg S J, Liu X M, Ibrahim S K, Pickett C J and Best S P 2007 Modeling Fe-Fe hydrogenase: evidence for bridging carbonyl and distal iron coordination vacancy in an electrocatalytically competent proton reduction by an iron thiolate assembly that operates through $\mathrm{Fe}(0)-\mathrm{Fe}(\mathrm{II})$ levels J. Am. Chem. Soc. 12911085

13. Zhong W, Zampella G, Li Z M, De Gioia L, Liu Y Q, Zeng X R, Luo Q Y and Liu X M 2008 Synthesis, characterisation of two hexa-iron clusters with $\left\{\mathrm{Fe}_{2} \mathrm{~S}_{2}(\mathrm{CO})_{\mathrm{x}}\right\}$ $(x=5$ or 6$)$ fragments and investigation into their interconversion J. Organomet. Chem. 6933751

14. Raubenheimer H G, Linford L and Lombard A V 1989 Preparation of Dinuclear Iron Carbonyl-Compounds Containing a 3-electron $\mathrm{CH}_{2}-\mathrm{S}$ Bridging Fragment Organometallics 82062

15. Ortega-Alfaro M C, Hernandez N, Cerna I, LopezCortes J G, Gomez E, Toscano R A and AlvarezToledano C 2004 Novel dinuclear iron(0) complexes from alpha,beta-unsaturated ketones beta-positioned with sulfide and sulfoxide groups J. Organomet. Chem. 689885

16. Harb M K, Niksch T, Windhager J, Gorls H, Holze R, Lockett L T, Okumura N, Evans D H, Glass R S, Lichtenberger D L, El-Khateeb M and Weigand W 2009 Synthesis and Characterization of Diiron Diselenolato Complexes Including Iron Hydrogenase Models Organometallics 281039

17. Royer A M, Rauchfuss T B and Gray D L 2009 Oxidative Addition of Thioesters to Iron(0): Active-Site Models for Hmd, Nature's Third Hydrogenase Organometallics 28 3618

18. Wang X F, Li Z M, Peng F, Ru X, Zeng X R, Luo Q Y and Liu X M 2009 Intramolecular formation and cleavage of $\mathrm{C}-\mathrm{S} / \mathrm{N}$ bonds promoted by iron-sulfur coordination chemistry Inorg. Chim. Acta $\mathbf{3 6 2} 2065$

19. Mousser H, Darchen A and Mousser A 2010 Unexpected fragmentation of phenyldithiobenzoate, formation and X-ray structure of mu,eta $2(\mathrm{~S}, \mathrm{~S})-1,2$-(dithio)1,2-(diphenylethylene) diiron hexacarbonyl complex $J$. Organomet. Chem. 695786

20. Royer A M, Salomone-Stagni M, Rauchfuss T B and Meyer-Klaucke W 2010 Iron Acyl Thiolato Carbonyls: Structural Models for the Active Site of the Fe Hydrogenase (Hmd) J. Am. Chem. Soc. 13216997

21. Song L C, Li Y L, Li L, Gu Z C and $\mathrm{Hu} \mathrm{Q}$ M 2010 Synthetic and Structural Investigations of Linear and Macrocyclic Nickel/Iron/Sulfur Cluster Complexes Inorg. Chem. 4910174

22. Windhager J, Apfel U P, Yoshino T, Nakata N, Gorls H, Rudolph M, Ishii A and Weigand W 2010 Reactions of 7,8-Dithiabicyclo 4.2.1 nona-2,4-diene 7-exo-Oxide 
with Dodecacarbonyl Triiron $\mathrm{Fe}_{3}(\mathrm{CO})_{12}$ : A Novel Type of Sulfenato Thiolato Diiron Hexacarbonyl Complexes Chem-Asian J. 51600

23. Winter A, Zsolnai L and Huttner G 1982 Dinuclear and trinuclear carbonylairon complexes containing 1,2dithiolato and 1,3-dithiolato bridging ligands Z. Naturforsch., B: Chem. Sci. 371430

24. Stanley J L, Rauchfuss T B and Wilson S R 2007 Studies on the condensation pathway to and properties of diiron azadithiolate carbonyls Organometallics 261907

25. Wang H Y, Xie Y M, King R B and Schaefer H F 2006 Remarkable aspects of unsaturation in trinuclear metal carbonyl clusters: The triiron species $\mathrm{Fe}_{3}(\mathrm{CO}) \mathrm{n}(\mathrm{n}=12$, 11, 10, 9) J. Am. Chem. Soc. 12811376

26. Kiasat A R and Mehrjardi M F 2008 A Novel One-Step Synthesis of Symmetrical Dialkyl Trithiocarbonates in the Presence of Phase-Transfer Catalysis J. Chin. Chem. Soc. $\mathbf{5 5} 639$

27. Lee A W M, Chan W H and Wong H C 1988 One Pot Phase Transfer Synthesis of Trithiocarbonates from Carbon Bisulphide and Alkyl Halides Synth. Commun. 18 1531

28. Larsen J and Lenoir C 1995 2,2'-Bi-5,6-Dihydro-1,3Dithiolo 4,5-B 1,4 Dithinylidene (BEDT-TTF) - (1,3Dithiolo 4,5-B 1,4 Dithiin, 2-(5,6-Dihydro-1,3-Dithiolo4,5-B 1,4 Dithiin-2-Ylidene)-5,6-DihydroI) Org. Synth. 72265

29. Archer C M, Dilworth J R, Griffiths D V, Al-Jeboori M J, Kelly J D, Lu C, Rosser M J and Zheng Y 1997 Technetium and rhenium oxo-complexes of new tetradentate ligands with $\mathrm{N}_{2}$ donor sets J. Chem. Soc. Dalton Trans. 1403

30. Long L, Xiao Z Y, Zampella G, Wei Z H, De Gioia L and Liu X M 2012 The reactions of pyridinyl thioesters with triiron dodecacarbonyl: their novel diiron carbonyl complexes and mechanistic investigations Dalton Trans. 419482
31. Seyferth D, Womack G B, Archer C M and Dewan J C 1989 A Simple Route to Hexacarbonyl Diiron Complexes Containing A Bridging Thiolate and An Organic Bridging Ligand by Means of $(\mu-\mathrm{RS})(\mu-$ $\mathrm{CO}) \mathrm{Fe}_{2}(\mathrm{CO})_{6}$ - Intermediates Organometallics 8 430

32. Volkers P I, Boyke C A, Chen J Z, Rauchfuss T B, Whaley C M, Wilson S R and Yao H J 2008 Precursors to FeFehydrogenase models: Syntheses of $\mathrm{Fe}_{2}(\mathrm{SR})_{2}(\mathrm{CO})_{6}$ from CO-free iron sources Inorg. Chem. 47 7002

33. Xiao Z Y, Xu FF, Long L, Liu Y Q, Zampella G, De Gioia L, Zeng X R, Luo Q Y and Liu X M 2010 Influence of the basicity of internal bases in diiron model complexes on hydrides formation and their transformation into protonated diiron hexacarbonyl J. Organomet. Chem. 695 721

34. Zhong W, Tang Y, Zampella G, Wang X F, Yang X L, Hu B, Wang J A, Xiao Z Y, Wei Z H, Chen H W, De Gioia L and Liu X M 2010 A rare bond between a soft metal $(\mathrm{Fe}(\mathrm{l}))$ and a relatively hard base $\left(\mathrm{RO}^{-}, \mathrm{R}=\right.$ phenolic moiety) Inorg. Chem. Commun. 131089

35. Tang Y, Wei Z H, Zhong W and Liu X M 2011 Diiron complexes with pendant phenol group(s) as mimics of the diiron subunit of FeFe -hydrogenase: Synthesis, characterisation, and electrochemical investigation Eur. J. Inorg. Chem. 1112

36. Tard C and Pickett C J 2009 Structural and Functional Analogues of the Active Sites of the Fe -, $\mathrm{NiFe}$-, and $\mathrm{FeFe}$-Hydrogenases Chem. Rev. 109 2245

37. Zeng $\mathrm{X} \mathrm{H}$, Li Z M, Xiao Z Y, Wang $\mathrm{Y} \mathrm{W}$ and Liu X M 2010 Using pendant ferrocenyl group(s) as an intramolecular standard to probe the reduction of diiron hexacarbonyl model complexes for the subunit of FeFe -hydrogenase Electrochem. Commun. 12 342 